\title{
Perspectives for cultivation of diversified crops in a rice (Oryza sativa L.)-based crop rotation in the Kyzylorda region, Kazakhstan
}

\author{
Tokhetova Laura ${ }^{1}$, Baizhanova Bibigul ${ }^{1 *}$, Baykenzhieva Ainur ${ }^{1}$, Kultasov Bekzat ${ }^{1}$, Tihomir Predić $^{2}$ \\ ${ }^{1}$ Kyzylorda University named after Korkyt Ata, Kyzylorda, Aiteke Bi str 29A, Republic of Kazakhstan \\ ${ }^{2}$ Agro-ecology Department, Agricultural Institute of the Republic of Srpska, Knjaza Miloša 17, \\ Banja Luka 78000, Bosnia and Herzegovina, e-mail: thho.predic@gmail.com \\ *Corresponding author: B. Baizhanova, email: bibi64@inbox.ru
}

\begin{abstract}
In the Aral Sea basin of Kyzylorda region, Kazakhstan, rice (Oryza sativa L.) is a main crop and annually occupies more than $45 \%$ of the total area of agricultural crops. However, about $90 \%$ of Syr Daria River waters is consumed for agricultural purposes, mainly for irrigation of paddy fields. In addition, there is an annual variability in the volume of water during the growing season, which creates certain threats to ensuring guaranteed water supply to irrigated lands and may pose a desertification risks. In addition, in the studied region, due to insufficient application of phosphorus fertilizers nutrient imbalance has been observed in the soil. The aim of the research was to develop sustainable production of rice by introduction of diversified cultures such as barley, soybean and rapeseed: Hordeum vulgare (L.), Glycine max (L.) and Brassica napus (L.), respectively, in a ricebased crop rotation and application of the different doses of mineral fertilizers in the Kyzylorda region. The results of the study showed that application of phosphorus as the main fertilizer at a dose of $90 \mathrm{~kg} \mathrm{ha}^{-1}$ gives a significant increase in yield. Studied barley and rapeseed crops showed better adaptability to the specific agroecological conditions. These crops are recommended to be introduced into the rice crop rotations in order to produce rice using environmentally friendly technology.
\end{abstract}

Keywords: diversification, fertilizer, rice, crop rotation, phosphorus.

\section{Introduction}

Desertification in Kazakhstan affects the country's environment, agriculture and animal husbandry. Due to the arid climate, water has become a priority in the socio-economic development of Aral sea region of south Kazakhstan. It is critical to quickly and accurately identify the locations of desertification land and grasp the main causes of desertification in different regions of Kazakhstan. Land desertification is a key land degradation process that affects the ecological environment and regional sustainable development in arid and semiarid regions of the world and directly affects a global population of more than 1 billion people and $40 \%$ of the total land surface (Verón et al. 2006). In monitoring studies of the Kyzylorda region, Yunfeng Hu et al. (2020) reported that approximately $24.1 \times 103 \mathrm{~km}^{2}$ of land, which accounts for $10.5 \%$ of all Kyzylorda territory, is in a state of desertification.

In Kyzylorda region, rice (Oryza sativa L.) is the main crop and annually occupies more than $45 \%$ of the total area under crops. The importance of rice for the region as an economic, ecological, and cultural is huge, while its role as a reclamation culture is invaluable. Irrigated agriculture 
consumes $90 \%$ of water in the Aral Sea basin (OECD 2020). The water resources of the Syr Darya river are expected to decrease by $20 \%$ by 2020 (REFS), and there is an annual variability in the volume of water during the growing season, which creates certain threats to ensuring guaranteed water supply to irrigated lands (Zou et al. 2019). According to the State Program for Water Resources Management of the Republic of Kazakhstan, it is expected to stabilize the rice cultivation area at the level of 60-65 thousand hectares until 2040. In addition, continuous cultivation of monculture, particularly rice, may results in deterioration of soil fertility and quality (Jat et al. 2012; Gutorova and Sheudzhen 2017; Hufnagel et al. 2020), rise of pests, diseases or weed problems (Hati et al. 2013; Sharma et al. 2017). Therefore, primary task for the Republics' agricultural sector is to introduce crop diversification by replacing the vacated areas with less water-consuming crops in the Kyzylorda region. It is possible through higher crop diversity in a crop rotation (Renard and Tilman 2019), mixed cropping (Bedoussac et al. 2015) cultivation of grain legumes in otherwise cereal dominated systems (Watson et al. 2017), and regionally adapted varieties or variety mixtures (Yang et al. 2019; Vijaya et al. 2019; Fita et al. 2015) as well as multiple cropping or intercropping.

Long-term cultivation of rice in the conditions of the Kyzylorda region led to a general rise in the level of groundwater in the fields where rice was cultivated, and in adjacent fields of natural agrophytocenoses where rice was not cultivated. This is exacerbated by the hot and dry climate, which causes strong evaporation of soil moisture, which intensifies salinization processes, especially when saline groundwater level is high (Funakawa et al. 2000; Kitamura et al. 2006; Funakawa and Kosaki 2007; Funakawa et al. 2007; Ibrakhmov et al. 2007; Orazkhan et al. 2016; Hamidov et al. 2016). The continuing processes of salinization of the territory are caused, on the one hand, by an increase in the salinity of irrigation water and groundwater, and, on the other hand, by insufficient drainage of the territory (Baimbetov et al. 2005).

According to scientists from the Kazakh Research Institute of Rice Cultivation, production of rice, allows reduction of soil salinity due to washing the salts downward. However, in order to obtain high rice yields and at the same time to combat desertification processes, new technologies need to be introduced adapted to the specific regional climatic and economic conditions. In the region, the active development of the livestock industry, the opening of a large feed mill and many feedlots have already created a high demand for fodder crops. Nowadays, alfalfa is actively introduced in the ricebased crop rotations. In addition, barley, wheat, millet, corn and other crops are in high demand in the region.

Cultivation of perennial grasses, mainly alfalfa, is the determining factor in maintaining and increasing soil fertility (Dedov et al. 2016; Bondarenko 2019). Many studies have shown that along with the traditional rice, crops such as barley, oats, rapeseed, sorghum, millet, soybeans, safflower may greatly contribute to a rational use of the bioclimatic potential of the region (Ray et al. 2009; Ali et al. 2012; Jat et al. 2012; Orazkhan et al. 2016; Cuevas et al. 2019; Hufnagel et al. 2020). The listed 
studies confirm that diversification of rice growing fields can both improve soil quality parameters and at the same time save water for irrigation. Particularly, in the semi desert of Aral Sea region where a shortage of irrigation water is highly urgent, upland crops can save water using the moisture accumulated after rice. They are able to form a high yield without a single irrigation. With a short growing season, these crops mature before the onset of the dry season and allow rational use of resources with the possibility of reusing these fields for other crops. Kui Liu et al. (2019) suggested that in changing climatic conditions, diversifying traditional rapeseed systems based on wheat or fallow using lentils and B. Junce (L.) will increase the system productivity and yield stability in different environments. Assefa et al. (2021) found that the rice-based cropping systems including diversified crops had a relatively higher income than traditional systems. In reviewing existing publications, Hamidov et al. (2016) found that there are many gaps in research knowledge regarding the agricultural land use to sustainable development in the Aral Sea basin. The hypothesis was that barley and rapeseed has a better adaptability to a specific climatic condition and therefore can be included in a rice-based crop rotation system in order to obtain organic rice production. The main goal of our research was to study effect of introduced diversified crops in three different rice-based croprotation systems and the effect of various doses of mineral fertilizers on indicators of productivity of diversified crops in the Aral Sea region, Kazakhstan.

\section{Description of the study site}

Kyzylorda region $\left(45^{\circ} 0^{\prime} \mathrm{N} 64^{\circ} 0^{\prime} \mathrm{E}\right)$ is located in the south of the Republic of Kazakhstan along the lower reaches of the Syr Darya River and occupies a significant part of the Turan lowland with a flat relief (50-200m above sea level). On the left bank of the Syr Darya River- vast expanses of hilly-ridge sands of the Kyzylkum desert. On the right bank of the Syr Darya there are hills (288 m), sands (Aryskum, etc.) and shallow basins occupied by Takyr-like salt marshes (Calcisols, WRB 2015). In the north, there are massifs of hilly sands. In the west the region includes the northern and eastern parts of the Aral Sea. Sands, almost devoid of vegetation, occupy a significant part of the territory. On fixed sands, wormwood-fescue and saltwort vegetation are grown. In spring, ephemeral plants also appear. The climate of the site studied is sharply continental and extremely arid with long hot and dry summers and relatively warm, short and little snowy winters. In the Kyzylorda region, an average temperature is $11.9^{\circ} \mathrm{C}$ and the amount of precipitation is about $100-140 \mathrm{~mm}$ per year. The experiment was a part of the ICARDA project that was conducted in 2017-2019.

The research was carried out at the research and production station of the LLP "KazNII of Rice Cultivation named after I. Zhakhaev”. Studied diversification crops were placed on the predecessor of rice. The soil of the experimental site was an Anthrosols Irragic (WRB 2015) with a low humus content of up to $1 \%$ and a high value of a dry residue $0.65-0.88 \%$. Salinity type is chloride-sulfate, moderately saline. 


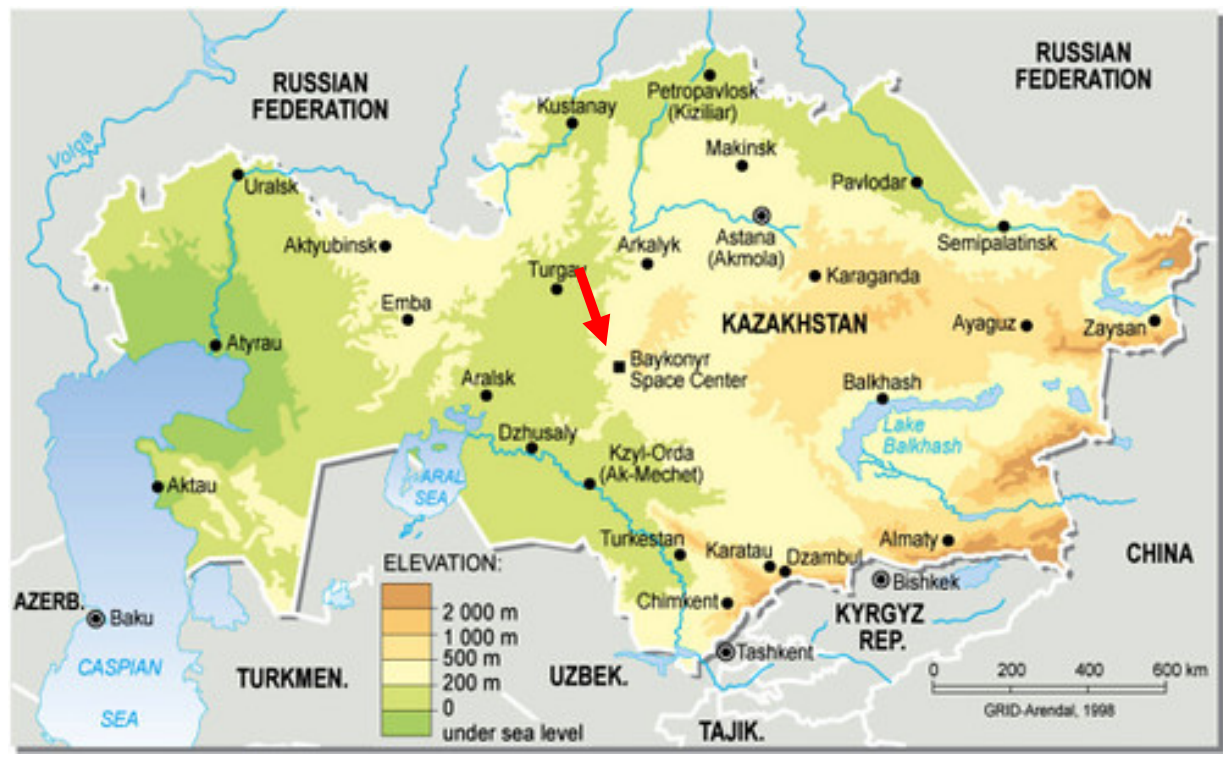

Figure 1. Map of Kazakhstan and the studied Kzyl-Orda region. (source: Philippe Rekacewicz, Emmanuelle Bournay, UNEP/GRID - Arendal (https://www.grida.no/resources/5348)

\section{Materials and methods}

Two field experiments were studied. In the rice-based crop rotation experiments, three schemes containing alfalfa, melilot and diversification crops (barley, wheat and oat) were studied and compared (Table 1). In the fertilization experiment, the diversification crops barley (Hordeum vulgare L.), soybeans (Glycine max L.) and rapeseed (Brassica campestris L.) were studied with four different doses of $\mathrm{N}: \mathrm{P}: \mathrm{K}$ fertilizers:

1. $\mathrm{N}_{0} \mathrm{P}_{0}$

2. $\mathrm{N}_{60} \mathrm{P}_{90}$

3. $\mathrm{N}_{90} \mathrm{P}_{90}$

4. $\mathrm{N}_{60+30} \mathrm{P}_{90}$

The object of research was domestic varieties of diversification crops: Barley -,,Asem”; soybean „Misula”; rapeseed- „Jubilee”. The area of each treatment (plot) was $50 \mathrm{~m}^{2}$, the seeding rates were: for barley - 4 million seeds per 1 ha; soybeans - 85 thousand seeds per ha; rapeseed 1.2 thousand seeds per ha. Germination was determined based on the number of grains per $1 \mathrm{~m}^{2}$ with the following values: barley - 400 pieces; soybeans - 85 pcs; rapeseed - 120 pcs.

Counting of the harvest was carried out on a plot basis. Determination of the qualitative composition of grain was carried out in the analytical laboratory of the Kazakh Research Institute of Agriculture and Crop Production (Almaty): protein content by the Kjeldahl method. Approximately 
$1 \mathrm{~g}$ of raw material was hydrolyzed with $15 \mathrm{~mL}$ concentrated sulfuric acid $\left(\mathrm{H}_{2} \mathrm{SO}_{4}\right)$ containing two copper catalyst tablets in a heat block at $420{ }^{\circ} \mathrm{C}$ for $2 \mathrm{~h}$. After cooling, $\mathrm{H}_{2} \mathrm{O}$ was added to the hydrolysates before neutralization and titration. The amount of total nitrogen in the raw materials were multiplied with both the traditional conversion factor of 6.25 (Kjeldahl 1883) and speciesspecific conversion factors (Lourenço et al. 2002) in order to determine total protein content. Starch was determined by the polarimetric method (Mineev 2001). This method includes a double polarimetric determination. In the first determination, the sample was treated with warm diluted hydrochloric acid, clarified and filtered. The optical rotation of the resulting solution was determined. In the second determination, the sample was extracted with $40 \%$ ethanol and filtered. The filtrate was acidified with hydrochloric acid, clarified and filtered again. The optical rotation of the resulting solution was determined. From the difference of both rotation angles the content of starch was calculated. The results were statistically processed by the analysis of variance according to Dospekhov (1973).

\section{Results and discussions}

\section{Crop rotations schemes}

Taking into account the results of our previous studies with barley (Tokhetova et al. 2017, 2020; Nurymova et al. 2020) we have developed new scientifically sound schemes of rice-based crop rotations with inclusion of diversified crops. The load of rice in a rotation was 37.5-50\% (Table 1).

Table 1. Place of diversified crops in the recommended rice-based crop rotation schemes

\begin{tabular}{|c|c|c|c|}
\hline $\begin{array}{l}\text { Field } \\
\text { no. }\end{array}$ & Scheme-1 & Scheme - 2 & Scheme - 3 \\
\hline 1 & $\mathrm{DC}+$ alfalfa & $\mathrm{DC}+$ alfalfa & $\mathrm{DC}+$ alfalfa \\
\hline 2 & Alfalfa $2^{\text {nd }}$ year & Alfalfa $2^{\text {nd }}$ year & Alfalfa $2^{\text {nd }}$ year \\
\hline 3 & Alfalfa $3^{\text {rd }}$ year & Alfalfa $3^{\text {rd }}$ year & Alfalfa $3^{\text {rd }}$ year \\
\hline 4 & Rice & Rice & Rice \\
\hline 5 & Rice & Rice & Rice \\
\hline 6 & DC + melilot & DC + sorghum & DC + melilot \\
\hline 7 & Melilot $2^{\text {nd }}$ year & Rice & Melilot for green manure + rice \\
\hline 8 & Rice & Rice & Rice \\
\hline $\begin{array}{l}\text { share of } \\
\text { crops in } \\
\text { the } \\
\text { rotation }\end{array}$ & $\begin{array}{l}\text { DC }-25 \% \text {; Alfalfa }-25 \% \\
(37.5 \%) ; \\
\text { Melilot }-12.5 \%(25 \%) ; \\
\text { Rice }-37.5 \%\end{array}$ & $\begin{array}{l}\text { DC - 25\% (sorghum - } \\
12.5 \%) ; \text { Alfalfa - 25\% } \\
(37,5 \%) ; \\
\text { Rice }-50 \%\end{array}$ & $\begin{array}{l}\text { DC - 25\%; } \\
\text { Alfalfa - 25\% (37.5\%); } \\
\text { Melilot - 25\%; } \\
\text { Rice - } 50 \%\end{array}$ \\
\hline
\end{tabular}

Note: DC - diversified cultures (barley, soybean and rapeseed)

In all three schemes, diversification crops were placed on the $1^{\text {st }}$ and $6^{\text {th }}$ fields after rice, which leaves a large supply of moisture, ensuring an even (simultaneous) shooting and respectively, the formation of an optimal stemming and total yield. Rice is a semi-aquatic plant, which requires a water-saturated environment during most of its life cycle (Qin et al. 2020) thus leaving high moisture reserves in soil. When placing crops on the post-rice fields, spring water-recharge irrigation is not 
carried out, since the available moisture ensures normal growth and development of plants throughout the growing season. This approach can be a part of the environmentally friendly rice-production.

Table 1 shows that diversification crops (DC) in the $1^{\text {st }}$ field are sown as cover crops of alfalfa. On the $6^{\text {th }}$ field of the $1^{\text {st }}$ and $3^{\text {rd }}$ crop rotation schemes, melilot is used as a cover crop, and on the $6^{\text {th }}$ field of the $2^{\text {nd }}$ scheme, DCs are sown. Because sorghum is a moderately salt-tolerant crop (Soni et al. 2021), after harvesting the DCs, it is possible successfully cultivate sorghum or millet as a second crop and green fodder. We suggest that this approach can contribute to a rational and effective use of lands because less irrigation will reduce secondary salinization at the same time saving water, while inclusion of DCs will facilitate maintaining soil health (Soni et al. 2021).

Long-term studies have shown that, under conditions of salinity or drought, specifically adapted varieties for local conditions show higher productivity than varieties of foreign-regional selection (Jung et al. 2020; Bohnert et al. 1995; Bray 1997; Chourey et al. 2003; Loescher et al. 2011; Goncharov and Goncharov 2009; CGIAR 2012; Pryanishnikov 2018). For example, inclusion of barley contributes to better weed control, thus being a field phytosanitary crop (Jabran 2017). At the same time, barley requires less water than wheat and rice (Khan et al. 2010) and is a more salt-tolerant crop. At the initial phase of the growing, barley grow quickly and intensively thus creating optimal conditions for the growth and development of perennial grasses on saline soils, shading them from direct sunlight (Khan et al. 2010). As a result of the short growing season, and therefore due to early harvesting of barley, the grasses released earlier from the cover crop and develop well in late summer and autumn, implying that it can be used as a cover crop in rice crop rotation too. After harvesting of the clean barley sowing, millet can be successfully cultivated, whose optimal sowing time coincides with the beginning of summer.

The role of alfalfa in a rice-based crop rotation, as a nitrogen-fixing crop, is very large, due to depositing nitrogen from air into soil in the form of protein substances. The latter, after mineralization, transforms into accessible for rice plants nitrogen (Pryanishnikov 1985; Wong 1980; Severov 2000; Posypanov 2007; Doev 2017; Chukhil 2017).

Perennial grasses leave behind a huge amount of organic residues in the form of roots, fallen leaves and stems (Alborova et al. 2012; Bondarenko 2019). When symbiotic nitrogen fixation is activated, alfalfa crops form a more powerful root system, and after harvesting, they leave about $2.9 \mathrm{t}$ $\mathrm{ha}^{-1}$ of organic matter and up to $55 \mathrm{~kg} \mathrm{ha}^{-1}$ of nitrogen in the soil. Besides, alfalfa helps to control weeds, including such malicious weed of rice fields as Phragmites australis (L.) (Doev 2017).

However, in Aral Sea region, a limiting factor in the diversification of crop production is a lack of varieties of oilseeds and legumes zoned in the Kyzylorda region. In this regard, there is a need to expand works on environmental testing of wider choice in the production of crop varieties, in order to select the most adapted to local conditions. 


\section{Fertilization experiment with inclusion of diversified crops}

Germination. Of all agricultural practices, one of the leading places in increasing the productivity of agricultural crops belongs to fertilizers. For the formation of a high yield, rapeseed requires an increased supply of mineral nutrients and, in turn, responds well to their presence in soil. On saline soils of rice systems with a dry residue $1.0 \%$ and more, germination of the crops is suppressed, which entails a strong inhibition of growth processes (Paul 2012; Qin et al. 2020). Bahizire (2007) reported that the emergence of 12 canola cultivars reduced by an electrical conductivity (EC) of $8 \mathrm{dS} \mathrm{m}^{-1}$. Some previous studies showed that rice yield decreases when saturated $\mathrm{EC}_{\mathrm{e}}$ is $>3.0 \mathrm{dS} \mathrm{m}^{-1}$, while $50 \%$ of yield loss is expected at 6-7 dS m${ }^{-1}$ (Maas and Hoffman 1977; Ayers and Westcot 1985; Francois and Maas 1999). Our results showed that on saline soils of rice systems, soybean plants did not show good development. In particular, their shoots appeared on the 19-21 $1^{\text {st }}$ day after sowing (Table 2), while the phase of full ripeness lasted until mid-September, implying poor growth intensity under the given conditions. On the contrary, rapeseed seedlings appeared very quickly and amicably, already on the $12-13^{\text {th }}$ day after sowing on April 17. The branching phase took place between May 11-17. The density of plants standing of rapeseed was higher than of soybean plants (Table 2).

In the treatment without fertilization, low germination was observed for soybean that amounted to only $29.4 \%$. For barley and rapeseed, the germination was 42.3 and $50.8 \%$, respectively. In comparison with other crops, application of mineral fertilizers on barley did not reveal any significant difference between the treatments. Only a slight increase by $2.3 \%$ in germination was noted on the $\mathrm{N}_{90} \mathrm{P}_{90}$ treatment compared with the control.

A different trend was observed for the soybean and rapeseed plants, where the application of nitrogen at a dose of $60 \mathrm{~kg}$ has led to a slight increase in seed germination by 9.4 and $5.0 \%$, respectively. And the application of phosphorus at a $90 \mathrm{~kg} \mathrm{ha}^{-1}$ dose in the treatments with nitrogen $\mathrm{N}_{60}$ and $\mathrm{N}_{90}$ resulted in a significant increase in seed germination, in particular, in the treatments with nitrogen and phosphorus at $90 \mathrm{~kg} \mathrm{ha}^{-1}$ : for soybeans by $14.1 \%$, for rapeseed $-9.2 \%$.

In ecologically unfavorable conditions of the Aral Sea region, the germination capacity of seeds in many respects depends on the completeness of seedlings, optimal stalk and total yield.

Plant development. The application of mineral fertilizers contributed to the lengthening of the vegetation of plants for all the crops. At the same time, a certain dynamics was observed: with an increase in the dose of fertilizers, the duration of the growing season increased by 2-3 days. No significant difference was found between the $\mathrm{N}_{60} \mathrm{P}_{90}$ and $\mathrm{N}_{60+30} \mathrm{P}_{90}$ treatments. An extension of the growing period by 6-8 days was noted on the $\mathrm{N}_{90} \mathrm{P}_{90}$ treatment in comparison with the control without fertilization. This favorably influenced the establishment and formation of generative organs. Therefore, in this treatment, the grain content in the barley ear and the number of seeds in the pod in rapeseed and soybeans was the highest. 
Plant height is one of the determining factors in the zoning of a particular variety of barley in the conditions of rice-based crop rotation in the Kyzylorda region, since it is mainly cultivated as a cover crop for perennial grasses. A similar pattern as for the growing period was observed for the height of plants. With an increase in the dose of mineral fertilizers, the plant height also increased. In the treatment $\mathrm{N}_{90} \mathrm{P}_{90}$, the height of barley plants was $65.1 \mathrm{~cm}$ against the control $53.5 \mathrm{~cm}$; in soybeans - $63.4 \mathrm{~cm}$, against the control $47.7 \mathrm{~cm}$; and in rape - $156.7 \mathrm{~cm}$, against the control $119.8 \mathrm{~cm}$.

As known, plant growth is inhibited on saline soils. One of the solution to this problem is the creation of salt-tolerant varieties of barley with the application of the optimal dose of mineral fertilizers. In our experiments, this was the treatment with $\mathrm{N}_{90} \mathrm{P}_{90}$, which allowed obtaining the barley plants with optimal stem size (above $60 \mathrm{~cm}$ ), which prevents the overgrowth of grasses above the cover crop.

The results showed a high responsiveness of the rapeseed crop to the application of mineral fertilizers. In the control treatment, the rapeseed yield was only $0.87 \mathrm{t} \mathrm{ha}^{-1}$, while in the fertilized treatments it reached $1.49-1.95 \mathrm{t} \mathrm{ha}^{-1}$, significantly exceeding it by $0.62-1.08 \mathrm{t} \mathrm{ha}^{-1}$, or $71.3-$ $124.1 \%$. An increase in the yield on soybean and barley was approximately the same amounting to 17.3 - 57.3\% and 16.5 - 52.6\%, respectively (Table 3).

Application of phosphorus, as the main fertilizer, in a dose of $90 \mathrm{~kg} \mathrm{ha}^{-1}$ resulted in a significant increase in the yield and other plant characteristics of all the crops studied. When comparing the $2^{\text {nd }}$ and $3^{\text {rd }}$ treatments, which are differing only in the dose of phosphorus fertilizers, a higher increase in yield was observed on barley $-0.35 \mathrm{t} \mathrm{ha}^{-1}$ and rapeseed $-0.23 \mathrm{t} \mathrm{ha}^{-1}$, while for soybean, the increase amounted to $0.13 \mathrm{t} \mathrm{ha}^{-1}$. This was because the soils of rice systems are very responsive to phosphorus on the studied region. There has long been an imbalance between the main types of nitrogen and phosphorus fertilizers, associated with the economic difficulties of rice-growing farms, where, phosphorus fertilizers are often not applied or are applied in insufficient quantities.

Analysis of grain quality of barley and soybeans showed that application of only $\mathrm{N}$ at a dose of $60 \mathrm{~kg}$ leads to both an increase in protein content and protein yield per hectare for both crops. A further increase in the dose of mineral fertilizers had a positive effect on the increase of protein content in barley grain and in soybean seeds. In particular, the $\mathrm{N}_{90} \mathrm{P}_{90}$ treatment provided a significant increase of the protein content, in comparison with the control treatment: in barley grain - $14.5 \%$, against the control variant - $11.5 \%$; in soybean seeds - 23.5\%, against the control - $20.5 \%$. However, although the protein content in grain of barley is almost two times inferior to soybeans, in terms of protein yield per hectare it exceeds by 0.13 tonnes, due to the higher grain yield. 

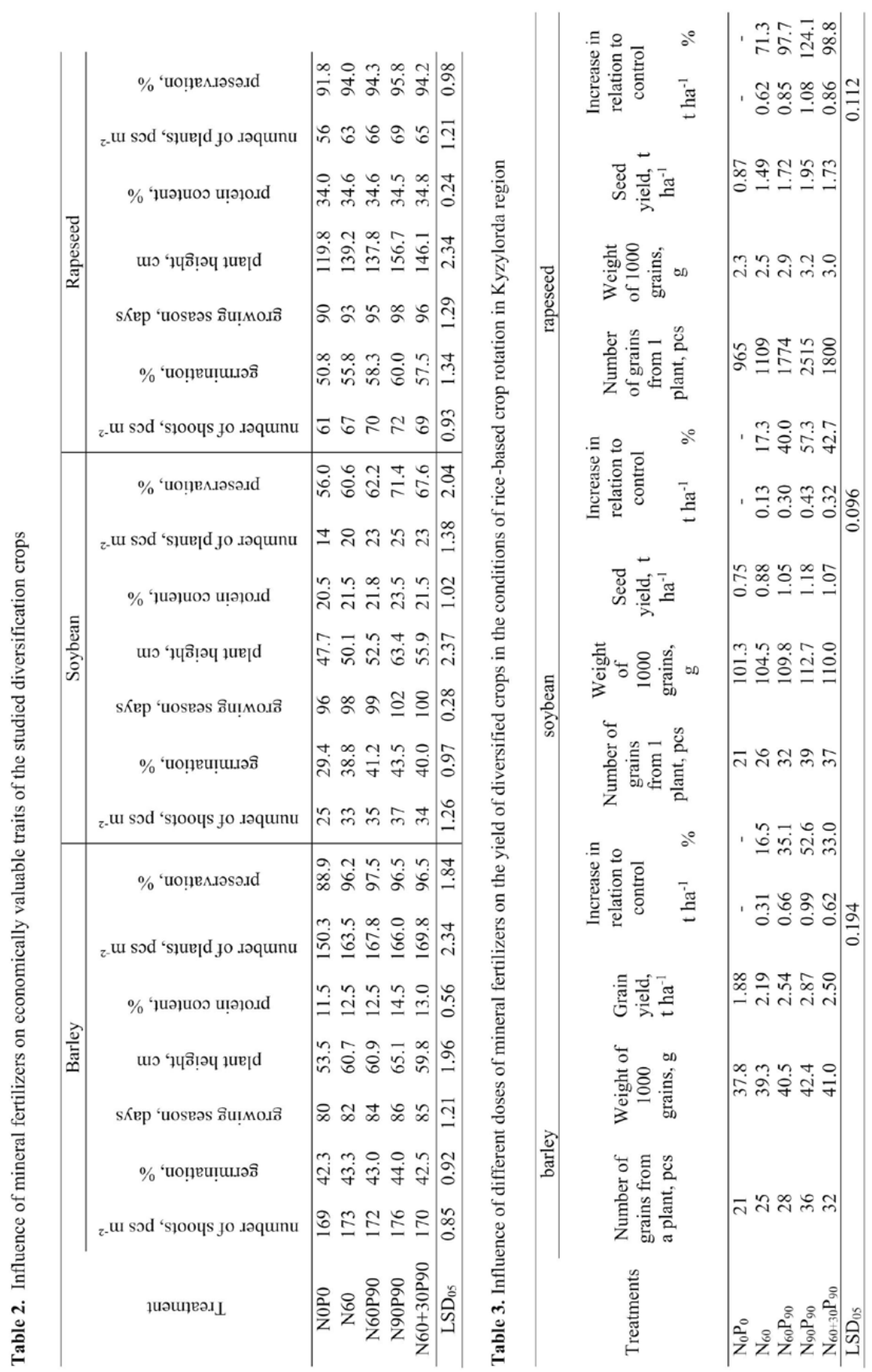

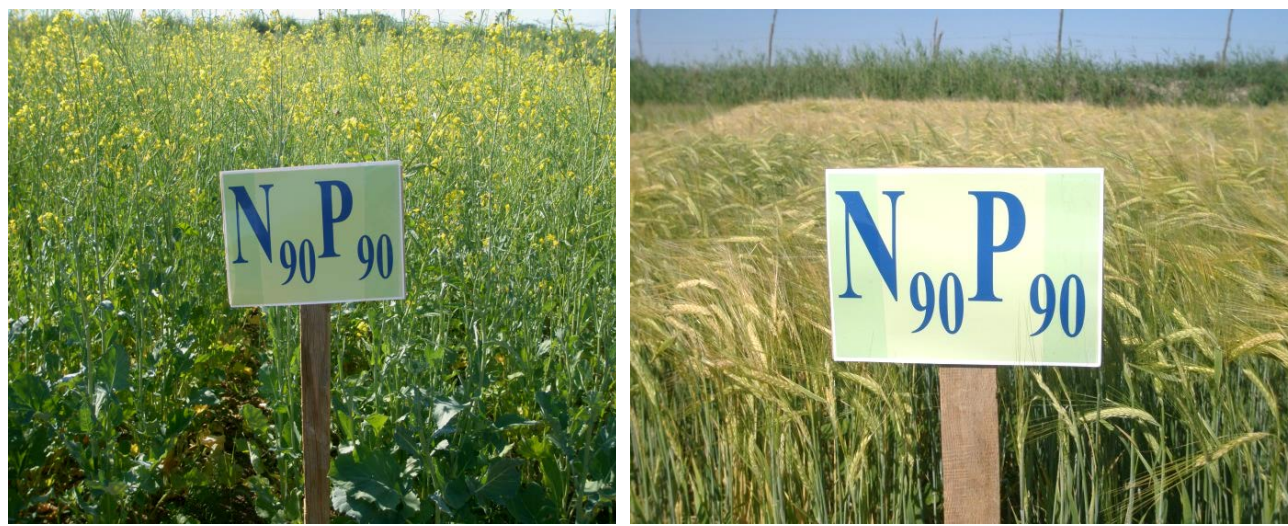

Figure 2. Rapeseed variety Yubileiny and barley Asem on the treatment with mineral fertilizers $\left(\mathrm{N}_{90} \mathrm{P}_{90}\right)$ in a rice-based crop rotation

In the study conducted, no significant relationship was found between the oil content in rape seeds and application of different doses of fertilizers. In the control treatment, oil content of the rape seeds was $34.0 \%$, which after application of mineral fertilizers ranged from 34.5 to $34.8 \%$, i.e. the difference was only $0.5-0.8 \%$. However, for the yield of oil from one hectare, this difference was significant, since it largely depends on the yield of seeds. The largest yield of oil was obtained on the $\mathrm{N}_{90} \mathrm{P}_{90}$ treatment $-0.67 \mathrm{t} \mathrm{ha}^{-1}$, which exceeds the control by $0.2 \mathrm{t} \mathrm{ha}^{-1}$ ( $\mathrm{LSD}_{05}-0.112$ ). Hence, it follows that the yield of oil from rapeseed seeds in our experiments largely depended on the yield of seeds, while the effect of mineral fertilizers was insignificant.

\section{General discussion}

Legumes are good precursors for other crops (Chibis and Chibis 2021) due to the inputs of fixed N, where for alfalfa, red clover, pea, soybean, cowpea, and vetch it is about 65 to $335 \mathrm{~kg}$ of $\mathrm{N}$ $\mathrm{ha}^{-1}$ year $^{-1}$ (Tate 1995) or 23 to $300 \mathrm{~kg}$ of $\mathrm{N} \mathrm{ha}^{-1}$ year $^{-1}$ (Wani 1995). Therefore, the rice yield is always higher after legumes, compared with rice-monoculture cropping. From grain crops, soybean is the most important protein-oil crop of world importance. Its seeds contain an average of $37-42 \%$ protein, $19-22 \%$ oil and up to 30\% carbohydrates (O’Keefe et al. 2015). The vegetative biomass of soybean is also rich in proteins, carbohydrates and vitamins (O’Keefe et al. 2015). Since this culture can be successfully used as food, fodder and industrial crop, its sowing area should be extended in the lower reaches of the Syrdarya River. Our study showed that the soil and climatic conditions of the region allow obtaining high yields of this crop, thereby solving the problems of vegetable protein and fodder.

Along with barley and soybean, a new rapeseed crop is of particular interest for improving the cropping structure, which contributes to increasing soil fertility and improving the assortment of oilseed productions. Because rapeseed is considered as a fast growing crop (Canola encyclopedia), it 
can be widely used as an intermediate crop or as an annual break crop to control pests and diseases (in three to four-year rotations with cereals such as wheat and barley, and break crops such as peas and beans (Alford 2008). It generally flowers in late spring with the process of pod development and ripening occurring over a period of 6-8 weeks until midsummer (Snowdon et al. 2006). Rapeseed also possesses a complex of such valuable qualities as a wide ecological adaptability, cold resistance, early maturity, high seed productivity, which favourably distinguishes it from many other crops (Oplinger et al. 1989; Fridrihsone et al. 2020). It can feed in early spring and extends the grazing season into the late autumn until the snow cover is established (Canola encyclopedia). In addition, rapeseed is a good predecessor crop. It contributes to a decrease in weed seed stocks by $14-22 \%$, the prevalence of the disease by 1.5 times, the development of root rot of cereals by 4.0 times and an increase in yield up to $0.3 \mathrm{t} \mathrm{ha}^{-1}$. In addition, rape stubble provides a wind-resistant field surface (Adyaev et al. 2007; Malakhov 1986; Savenkov 1997)

Obtaining high and stable yields of any crop is possible only with its correct placement in the crop rotation. Currently, the farms of the Kyzylorda region have 271 rice-based crop rotations, most of which are eight-year length. They have one field for grain crops (winter wheat, spring wheat or spring barley) where they are grown as a single crop or as cover crops for perennial grasses such as alfalfa. In our proposed schemes, two fields are allocated for sowing cereal crops.

\section{Conclusions}

1. In the fallow field of rice-based crop rotation, more even shooting was observed for barley and rape compared to soybean, because soybean requires integrated protection against pests and diseases in the initial phase of ontogenesis. Since barley and rapeseed showed better adaptability to the specific agro-ecological conditions in the rice-based crop rotation, they are recommended as rice precursors for cultivation in a fallow field in order to obtain organic rice production.

2. Application of mineral fertilizers to the diversified crops influenced the lengthening of the growing season, which had a positive effect on the growth and development of plants, especially barley. Application of the mineral fertilizer resulted in a 6-8 $\mathrm{cm}$ increase of the plant height and formation of a larger ears of barley, compared to the control.

3. To diversify crop production sector of the Kyzylorda region, preliminary scientific and practical basis and production conditions have been created. Given the expected shortage of irrigation water, this integration of the less water-consuming crops into a rice crop rotation.

4. In the conditions of the Aral Sea environmental crisis, diversification of the crop production industry contributes to an improvement of the ecological situation in the region and restoration of soil productivity. 
5. Further research should be focused on determination of an optimal area for sowing rice and a most rational placement of diversified crops in the irrigation zones of the region.

\section{References}

Adyaev S.B., Dedova E.B., Sazanov M.A., Nidzhlyaeva I.A. 2007. Recommendations for the cultivation of accompanying crops of rice-based crop rotations in the Sarpinskaya lowland. O.V. Demkina (ed), Elista, pp. 20.

Alborova P.V., Kosyrev A.Kh., Sabanova A.A. 2012. The use of yellow melilot as an early precursor for winter crops and catch crops. News of the Gorsky State Agrarian University, 49(4):71-76

Alford D.V. 2008. Biocontrol of Oilseed Rape Pests. Wiley. ISBN 9781405171564.

Ali R.I., Awan T.H., Ahmad M., Saleem M.U., Akhtar M. 2012. Diversification of rice-based cropping systems to improve soil fertility, sustainable productivity and economics. The Journal of Animal \& Plant Sciences, 22(1):108-112.

Ayers R.S., Westcot D.W. 1985. Water Quality for Agriculture. FAO Irrigation and Drainage Paper 29 Rev. 1. Rome, Italy: Food and Agriculture Organization of the United Nations.

Baimbetov K., Sagimbayev S. 2005. Agromeliorative monitoring of irrigated lands and prospects for rice planting in the Aral Sea region. Bulletin of agricultural science of Kazakhstan 4:12-14 https://nauka.kz/page.php?lang=1\&page=1655\&page_id=794

Bahizire F.B. 2007. Effect of salinity on germination and seeding growth of canola (Brassica napus L.). MSc Thesis, March 2007, University of Stellenbosch.

Bedoussac L., Journet E-P., Hauggaard-Nielsen H., Naudin C., Corre-Hellou G., Jensen E.S., Prieur L., Justes E. 2015. Ecological principles underlying the increase of productivity achieved by cereal-grain legume intercrops in organic farming. A review. Agron Sustain Dev 35(3):911935. https://doi.org/10.1007/s13593-014-0277-7

Bondarenko I.I. 2019. Bioecological features of pathogenic complex of micromycetes of federal lucerne in conditions of the Northwestern Precaucasia. Ph. D. thesis. Kuban State Agrarian University Named after I.T. Trubilina. Krasnodar. Russia

Bohnert HJ, Nelson DE, Jensen RG. 1995. Adaptations to environmental stresses. The Plant Cell 7: 1099-111.

Bray E. 1997. Plant responses to water deficit. Trends Plant Sci 2: 48-54.

Canola encyclopedia, https://www.canolacouncil.org/canola-encyclopedia/growth-stages/)

CGIAR Report. 2012. Regional Program of the CGIAR for sustainable development agriculture in Central Asia and the South Caucasus, pp. 87. http://cacprogram.org/files/15scm_cac_annual_report_ru.pdf 
Chibis V.V., Chibis S.P. 2021. Ecologization of crop industry by introducing a bean component into the field crop rotation of Western Siberia. IOP Conference Series: Earth and Environmental Science. 624, 012221. https://doi.org/10.1088/1755-1315/624/1/012221

Chukhil A.A. 2017. Productivity of alfalfa in the second year of life at optimization of mineral nutrition of plants on leached chernozem western Caucasus. Ph.D. thesis. Kuban State Agrarian University named after I.T. Trubilina. Krasnodar. Russia

Cuevas J., Daliakopoulos I.N., Del Moral F., Hueso J.J., Tsanis I.K. 2019. A Review of SoilImproving Cropping Systems for Soil Salinization. Agronomy 9, 295; doi:10.3390/agronomy9060295

Chourey K, Ramani S, Apte SK. 2003. Accumulation of LEA proteins in salt (NaCL) stressed young seedlings of rice (Oryza sativa L.) cultivar Bura Rata and their degradation during recovery from salinity stress. J. Plant Physiol. 160:1165-1174.

Dedov A.A., Dedov A.V., Nesmeyanova M.A. 2016. Technology of cultivation of blue alfalfa for forage purposes. Feed production 12:24-29

Doev D.N. 2017. Assessment of bioresource potential of alfalfa (Medicago varia Mart.) when using local strains of nodule bacteria of the genus Sinorhizobium under conditions of vertical zoning of rno-alania. PhD thesis. Gorsk State Agrarian University, Vladikavkaz, Russia.

Dospekhov B.A. 1973. Field experiment technique. Moscow, Kolos, pp. 335.

Fita A., Rodríguez-Burruezo A., Boscaiu M., Prohens J., Vicente O. 2015. Breeding and Domesticating Crops Adapted to Drought and Salinity: A New Paradigm for Increasing Food Production. Frontiers in Plant Science 12. https://doi.org/10.3389/fpls.2015.00978

Francois L.E., Maas E.V. 1999. “Crop Response and Management of Salt-affected Soils.” In Hand Book of Plant and Crop Stress, edited by M.Pessarakli , 169-201. New York: Marcel Dekker.

Fridrihson A., Romagnoli F., Cabulis U. 2020. Environmental Life Cycle Assessment of Rapeseed and Rapeseed Oil Produced in Northern Europe: A Latvian Case Study. Sustainability 12, 5699; doi:10.3390/su12145699

Funakawa S., Kosaki T. 2007. Potential risk of soil salinization in different regions of Central Asia with special reference to salt reserves in deep layers of soils. Soil Science and Plant Nutrition 53(5): 634-649. https://doi.org/10.1111/j.1747-0765.2007.00186.x

Funakawa S., Suzuki R., Kanaya Sh., Karbozova Saljnikov E., Kosaki T. 2007. Distribution patterns of soluble salts and gypsum in soils under large-scale irrigation agriculture in Central Asia. Soil Science and Plant Nutrition 53(2):150-161, https://doi.org/10.1111/j.1747-0765.2007.00115.x

Funakawa S., Suzuki R., Karbozova E., Kosaki T., Ishida N. 2000. Salt-affected soils under rice-base irrigation agriculture in southern Kazakhstan. Geoderma 97:61-85 
Goncharov N.P., Goncharov P.L. 2009. Methodical bases of plant breeding. Edition: 2nd Publisher: Publ. House of SB RAS, Novosibirsk, V.K. Shumny (Eds), ISBN: 978-5-9747-0169-6. https://www.researchgate.net/publication/275352146_Methodical_bases_of_plant_breeding

Gutorova O.A., Sheudzhen A.K. 2017. Morphogenesis of rice meadow-boggy soils in Kuban River region. Russ. Agricult. Sci. 43:40-43. https://doi.org/10.3103/S1068367417010098

Hamidov A., Helming K., Balla D. 2016. Impact of agricultural land use in Central Asia: a review. Agron. Sustain. Dev. 36, 6. https://doi.org/10.1007/s13593-015-0337-7

Hati K.M., Chaudhary R.S., Mandal K.G., Misra A.K., Singh R.K., Wani S.P., Singh P., Pathak P. 2013. Effect of land management and cropping systems on runoff, soil loss, soil water dynamics and crop yield in a vertisol of Central India. J Indian Soc Soil Sci 61(2):79-88

Hufnagel J., Reckling M., Ewert F. 2020. Diverse approaches to crop diversification in agricultural research. A review. Agron. Sustain. Dev. 40, 14. https://doi.org/10.1007/s13593-020-00617-4

Ibrakhmov M., Khamzina A., Forkutsa I., Paluasheva G., Lamers J.P.A., Tischbein B., Vlek P.L.G., Martius C. 2007. Groundwater table and salinity: Spatial and temporal distribution and influence on soil salinization in Khorezm region (Uzbekistan, Aral Sea Basin). Irrig Drainage Syst 21:219-236. https://doi.org/10.1007/s10795-007-9033-3

Jabran K. 2017. Barley allelopathy for weed control. In: K. Jabran (Eds), Manipulation of Allelopathic Crops for Weed Control. Springe rBriefs in Plant Science, Springer International Publishing AG, Switzerland. pp. 57-63. DOI: 10.1007/978-3-319-53186-1 7

Jat R.A., Dungrani R.A., Arvadia M.K., Kanwar L.S. 2012. Diversification of rice (Oryza sativa L.)based cropping system for higher productivity, resource-use efficiency and economic returs in south Gujarat, India. Archives of Agronomy and Soil Science, 58(4-6):561-572. http://dx.doi.org/10.1080/03650340.2010.533172

Jung S., de Vos A., Zambujo J. 2020. Soil salinization. European Commission, EIP-AGRI Focus Group, $\quad$ pp.8. https://ec.europa.eu/eip/agriculture/sites/agrieip/files/fg36_minipaper_salttolerantcrops_2020_en.pdf

Khan S., Khan M.A., Latif N. 2010. Energy requirements and economic analysis of wheat, rice and barley production in Australia. Plant Soil and Environment 21(1):61-68

Kjeldahl J. 1883. Neue Methode zur Bestimmung des Stickstoffs in organischen Körpern. Fresenius' J. Anal. Chem. 22: 366-382. doi: 10.1007/BF01338151

Kitamura Y., Yano T., Honna T., Yamamoto S., Inosako K. 2006. Causes of farmland salinization and remedial measures in the Aral Sea basin - Research on water management to prevent secondary salinization in rice-based cropping system in and land. Agricultural Water Management 85(12):1-14. https://doi.org/10.1016/j.agwat.2006.03.007

Kui Liu E., Johnson N., Blackshaw R.E. 2019. Improving the productivity and stability of oilseed cropping systems through crop diversification. Field Crops Research 237:65-73 
Loescher W., Chan Zh., Grumet R. 2011. Options for developing salt-tolerant crops. Horticulture

Science 46(8):1085-1092. https://doi.org/10.21273/HORTSCI.46.8.1085

Lourenço S.O., Barbarino E., De-Paula J.C., Pereira L.O.d.S., Lanfer Marquez U.M. 2002. Amino acid composition, protein content and calculation of nitrogen-to-protein conversion factors for 19 tropical seaweeds. Phycol. Res. 50:233-241. doi: 10.1111/j.1440-1835.2002.tb00156.x.

Maas E.V., Hoffman G.J. 1977. Crop Salt Tolerance - Current Assessment. ASCE Journal of the Irrigation and Drainage Division 103:115-134

Malakhov G.N. 1986. Rape is a high-yielding crop. Chelyabinsk, South Ural Publishing House, pp. 44. Mineev V.G. 2001. Workshop on agrochemistry Moscow State University Publishing House, 689 pp

Nurymova R., Tokhetova L., Baizhanova B. 2020. Influence of barley seeding rate and fertilizer dose on the yield of melilot in the sub-cover sowing in the rice crop rotation. Zemljište i Biljka 69(1):65-73. DOI: 10.5937/ZemBilj2001065N

OECD 2020. Overview of the use and management of water resources in Central Asia. GREEN Action Task Force. https://issuu.com/oecd.publishing/docs/final_report_eng_issuu, http://oe.cd/EUWI

O’Keefe S., Bianchi L., Sharman J. 2015. Soybean Nutrition. SM J Nutr Metab. 1(2): 1006.

Oplinger E.S., Hardman L.L., Gritton E.T., Doll J.D., Kelling K.A. 1989. Canola (Rapeseed). Alternative Field Crops Manual. University of Wiskonsin-Extension, University of Minnesota; https://hort.purdue.edu/newcrop/afcm/canola.html

Orazkhan K., Karlykhanov K., Toktaganova G.B. 2016. The Assessment of Irrigated Land Salinization in the Aral Sea Region. International Journal of Environmental \& Science Education, 11(15):7946-7960. https://files.eric.ed.gov/fulltext/EJ1117649.pdf

Paul D. 2012. Osmotic stress adaptations in rhizobacteria. J. Basic Microbiol. 52:1-10

Posypanov G.S., Dolgodvorov V.E., Zherukov B.Kh. 2007. Alfalfa. Crop Production. Moscow, Kolos, pp. 417-423.

Pryanishnikov D.N. 1985. Selected works, vol. 2, Moscow, Kolos, pp. 451.

Pryanishnikov A.I. 2018. The scientific basis of adaptive breeding in the Volga region. Moscow, Russian Academy of Sciences, pp.96. ISBN 978-5-906906-87-8

Qin H., Li Y., Huang R. 2020. Advances and challenges in the breeding of salt-tolerant rice. Int. J. Mol. Sci. 21(21), 8385. https://doi.org/10.3390/ijms21218385

Ray M., Chatterjee S., Pramanick M., Mani P.K., Roy K., Sengupta K. 2009. Diversification of ricebased cropping system and their impact on energy utilization and system production. Journal of Crop and Weed, 5(1):162-165.

Renard D, Tilman D (2019) National food production stabilized by crop diversity. Nature 571:257260. https://doi.org/10.1038/s41586-019-1316-y

Savenkov V.P. 1997. Spring rape for oilseeds. Feed production 4:16-17. 
Severov V.I., Kalashnikov K.G. 2000. Perennial grasses are the basis of modern forage production and biologic farming. Tula, pp. 38

Sharma NK, Singh RJ, Mandal D, Kumar A, Alam NM, Keesstra S (2017) Increasing farmer's income and reducing soil erosion using intercropping in rainfed maize-wheat rotation of Himalaya, India. Agric Ecosyst Environ 247:43-53. https://doi.org/10.1016/j.agee.2017.06.026

Snowdon R., Wilfried L., Wolfgang F. 2006. Genome Mapping and Molecular Breeding in Plants Oilseeds. Springer. $\underline{\text { ISBN }} \underline{9783540343875}$

Soni P.G., Basak N., Rai A.K. et al. 2021. Deficit saline water irrigation under reduced tillage and residue mulch improves soil health in sorghum-wheat cropping system in semi-arid region. Sci Rep 11, 1880. https://doi.org/10.1038/s41598-020-80364-4

Tate R.L. 1995. Soil microbiology (symbiotic nitrogen fixation) New York, N.Y: John Wiley \& Sons, Inc.; pp. 307-333.

Tokhetova L., Tautenov I., Zelinskii G., Demesinova A. 2017. Variability of main quantitative traits of the spring barley in different environmental conditions. Ecology, Environment and Conservation 23(2):1093-1098

Tokhetova L.A., Umirzakov S.I., Nurymova R.D., Baizhanova B.K., Akhmedova G.B. 2020. Analysis of Economic-Biological Traits of Hull-Less Barley and Creation of Source Material for Resistance to Environmental Stress Factors. International Journal of Agronomy 2020:8847753. https://doi.org/10.1155/2020/8847753

Verón S.R., Paruelo J.M., Oesterheld M. 2006. Assessing desertification. Journal of Arid Environments 66(4):751-763 https://doi.org/10.1016/j.jaridenv.2006.01.021

Vijaya B.A.V., Baresel J.P., Weedon O., Finckh M.R. 2019. Effects of ten years organic and conventional farming on early seedling traits of evolving winter wheat composite cross populations. Sci Rep 9(1): 9053. https://doi.org/10.1038/s41598-019-45300-1

Wani S.P., Rupela O.P., Lee K.K. 1995. Sustainable agriculture in the semi-arid tropics through biological nitrogen fixation in grain legumes. Plant Soil 174:29-49.

Watson C., Reckling M., Preissel S., Bachinger J., Bergkvist G., Kuhlman T., Lindström K., Nemecek T., Topp C., Vanhatalo A., Zander Z., Murphy-Bokern D., Stoddard F. 2017. Grain legume production and use in European agricultural systems. Adv Agron 144(1):235-303

Wong P.P. 1980. Nitrate and carbohydrate effects on nodulation and nitrogen fixation (Acetylene reduction) activity of lentil. Plant Physiol 66

WRB 2015. World reference base for soil resources 2014. Food and Agriculture Organization of the United Nations Rome, 2015, p 192

Yang L-N., Pan Z-C., Zhu W., Wu E.J., He D-C., Yuan X., Qin Y-Y., Wang Y., Chen R-S., Thrall P.H., Burdon J.J., Shang L-P., Sui Q-J., Zhan J. 2019. Enhanced agricultural sustainability 
through within-species diversification. Nat Sustain 2(1):46-52. https://doi.org/10.1038/s41893$\underline{018-0201-2}$

Assefa Y., Yadav S. et al. 2021. Crop diversification in rice-based systems in the polders of Bangladesh: Yield stability, profitability and associated risk. Agricultural Systems 187:102986. https://doi.org/10.1016/j.agsy.2020.102986

Yunfeng Hu, Yueqi Han, Yunzhi Zhang. 2020. Land desertification and its influencing factors in $\begin{array}{llll}\text { Kazakhstan. Journal of Arid Environments } & \text { 180:104203 }\end{array}$ https://doi.org/10.1016/j.jaridenv.2020.104203

Zou S., Jilili A., Duan W., De Maeyer P., Van de Voorde T. 2019. Human and natural impacts on the water resources in the Syr Daria River basin, Central Asia. Sustainability 11:3084. doi:10.3390/su11113084 


\section{Perspektive za kultivaciju raznolikih useva u plodored zanovan na pirinču (Oryza sativa L.) u regionu Kizilorda, Kazahstan}

Tokhetova Laura $^{1}$, Baizhanova Bibigul ${ }^{1 *}$, Baykenzhieva Ainur ${ }^{1}$, Kultasov Bekzat $^{1}$, Tihomir Predić ${ }^{2}$

${ }^{1}$ Kyzylorda University named after Korkyt Ata, Kyzylorda, Aiteke Bi str 29A, Republic of Kazakhstan

${ }^{2}$ Agro-ecology Department, Agricultural Institute of the Republic of Srpska, Knjaza Miloša 17,

Banja Luka 78000, Bosnia and Herzegovina, e-mail: thho.predic@gmail.com

*Corresponding author: B. Baizhanova, email: bibi64@inbox.ru

\section{Izvod}

U slivu Aralskog mora regije Kyzylorda, Kazahstan, pirinač (Oryza sativa L.) je glavna kultura i godišnje zauzima vise od $45 \%$ ukupne površine poljoprivrednih kultura. Međutim, oko $90 \%$ vode reke Sir Daria troši se u poljoprivredne svrhe, uglavnom za navodnjavanje pirinčanih polja. Takođe, postoji godišnja varijabilnost u količini vode tokom vegetacione sezone, što stvara određene pretnje po pitanju zagarantovanog snabdevanja vodom navodnjavanog zemljišta i može predstavljati rizik dezertifikacije. Pored toga, u proučavanom regionu, zbog nedovoljne primene fosfornih đubriva, primećena je neravnoteza hranljivih sastojaka u zemljištu. Cilj istraživanja je bio da se razvije održiva proizvodnja pirinča uvođenjem raznolikih kultura poput ječma, soje i uljane repice: Hordeum vulgare (L.), Glycine max (L.) i Brassica napus (L.), u plodored pirinča i primenom različitih doza mineralnih đubriva u regionu Kyzylorda. Rezultati studije pokazali su da primena fosfora kao glavnog đubriva u dozi od $90 \mathrm{~kg} \mathrm{ha}^{-1}$ daje značajn porast prinosa. Proučavani usevi, ječm i uljana repica, pokazali su bolju prilagodljivost specifičnim agroekološkim uslovima. Preporučuje se da se ovi usevi uvode u plodored zasnovan na pirinču u cilju korišćenja ekoloških tehnologija u proizvodnji pirinča.

Ključne reči: diverzifikacija, đubrivo, pirinač, plodored, fosfor 